\title{
Modulation of T cell function through L-arginine metabolism: a new therapy from an old enemy
}

\author{
Matthew Fletcher ${ }^{1,3}$, Maria E Ramirez ${ }^{1}$, Rosa Sierra', Patrick Raber ${ }^{1,2}$, Paulo Rodriguez ${ }^{1,2^{*}}$ \\ From Society for Immunotherapy of Cancer 28th Annual Meeting \\ National Harbor, MD, USA. 8-10 November 2013
}

Recent studies have suggested the relevance of different energy metabolic pathways in the balance between protective $\mathrm{T}$ cell immunity and T cell anergy in tumors. We and others have suggested the role of the depletion of the nonessential amino acid L-arginine as a mechanism for the induction of $\mathrm{T}$ cell suppression in tumors. Therefore, we hypothesize that it is possible to metabolically regulate $\mathrm{T}$ cell responses simply through the modulation of $\mathrm{L}$-arginine. In this study, we aimed to determine the effect of a pegylated form of the human L-arginine-metabolizing enzyme arginase I (peg-Arg I) in T cell responses. Activation of antigen-specific CD4+ and CD8+ T cells in the presence of peg-Arg I prevented cell proliferation and production of IFN $\gamma$ in vitro and in vivo. Similarly, peg-Arg I impaired proliferation and IFN $\gamma$ production in T cells activated with PMA/Ionomycin, suggesting that the effect of peg-Arg I was independent of $\mathrm{T}$ cell receptor (TCR) signaling. In fact, the anti-proliferative effect induced by peg-Arg I correlated with an arrest of $\mathrm{T}$ cells in the G0-G1 phase of the cell cycle, a decreased expression of cyclin D3 and cdk4, and a major inhibition of de novo translation. Interestingly, treatment of $\mathrm{T}$ cells with peg-Arg I did not impair the expression of activation markers CD25, CD69, and the production of IL-2, which correlated with an intact mitochondrial biogenesis. As a result, peg-Arg I did not have an effect in oxygen consumption (OCR) by mitochondrial respiration, but significantly blocked glycolytic pathways in activated T cells. Furthermore, peg-Arg I treated T cells increased the expression of genes associated with integrated stress responses (IRS) and arrest in translation including GCN2, Chop, and Atf4. In fact, GCN2 was a major mediator of the effects induced by peg-Arg I. Then, we tested the effect of peg-Arg I in mouse models of graft versus host disease (GVHD) and inflammatory bowel disease (IBD), both

${ }^{1}$ Stanley S. Scott Cancer Center, Louisiana State University Health Sciences

Center, New Orleans, LA, USA

Full list of author information is available at the end of the article mediated through activated T cells. Peg-Arg I significantly extended the survival of mice in these 2 disease models, which associated with a decreased production of IFN $\gamma$. Altogether the results suggest the potential effect of the modulation of the metabolism of L-arginine as a mean to modulate $T$ cell responses. Continuation of this study will advance in the understanding of the metabolic effects of $\mathrm{L}$-arginine in $\mathrm{T}$ cell function, which could enable the development of therapies to modulate $\mathrm{T}$ cell responses in transplantation or autoimmunity.

\section{Authors' details}

${ }^{1}$ Stanley S. Scott Cancer Center, Louisiana State University Health Sciences Center, New Orleans, LA, USA. ²Department of Microbiology, Immunology and Parasitology, Louisiana State University Health Sciences Center, New Orleans, LA, USA. ${ }^{3}$ Department of Pediatrics, Louisiana State University Health Sciences Center, New Orleans, LA, USA.

Published: 7 November 2013

doi:10.1186/2051-1426-1-S1-010

Cite this article as: Fletcher et al:: Modulation of $\mathrm{T}$ cell function through

L-arginine metabolism: a new therapy from an old enemy. Journal for ImmunoTherapy of Cancer 2013 1(Suppl 1):010.

Submit your next manuscript to BioMed Central and take full advantage of:

- Convenient online submission

- Thorough peer review

- No space constraints or color figure charges

- Immediate publication on acceptance

- Inclusion in PubMed, CAS, Scopus and Google Scholar

- Research which is freely available for redistribution
C Biomed Central

ㄷ 2013 Fletcher et al; licensee BioMed Central Ltd. This is an Open Access article distributed under the terms of the Creative Commons Attribution License (http://creativecommons.org/licenses/by/2.0), which permits unrestricted use, distribution, and reproduction in any medium, provided the original work is properly cited. 